\title{
Characterization and selection of native yeast isolated from natural fermentation for the production of the artisanal beverage bacanora
}

\author{
Caracterización y selección de levaduras nativas aisladas de la fermentación natural de la producción \\ artesanal de la bebida bacanora
}

Maritza Lizeth Alvarez-Ainza ${ }^{1,2 *}$, Alfonso García-Galaz², Humberto González-Ríos ${ }^{3}$, Griselda Macrina Moreno-lbarra' Mayra De la Torre-Martínez², Karina Alejandra Zamora-Quiñones², Evelia Acedo-Félix ${ }^{2,+}$

1 Laboratorio de Microbiología, Departamento de Ciencias Químico-Biológicas, Universidad de Sonora, Boulevard Luis Encinas y Rosales s/n, C.P. 83000, Hermosillo, Sonora, México.

2 Coordinación de Ciencia de los Alimentos. Centro de Investigación en Alimentación y Desarrollo, A.C. Carretera a la Victoria Km 0.6, P.O. Box 1735, Hermosillo, Sonora, México.

3 Coordinación de Ciencia de los Alimentos de Origen Animal. Centro de Investigación en Alimentación y Desarrollo, A.C. Carretera a la Victoria Km 0.6, P.O. Box 1735, Hermosillo, Sonora, México.

\section{ABSTRACT}

Bacanora is a Mexican distilled beverage made from agave, similar to tequila and mezcal, produced with an artisanal process. Therefore, the organoleptic characteristics of different bacanora vary highly. The aim of this study was to characterize and select native yeast involved in this artisanal process of fermentation. An initial pre-selection based upon the phenotypic characteristics of 580 strains of yeast was done, and then based on fermentation characteristics with agave juice. After pre-selection, three Saccharomyces cerevisiae and three non-Saccharomyces were chosen for the fermentative characterization. The $S$. cerevisiae yeasts produced $25.51 \pm 1.19 \mathrm{~g} / \mathrm{L}$ of ethanol at the end of the fermentation process, with a volumetric ethanol productivity of $1.76 \pm 0.17 \mathrm{~g} / \mathrm{L} / \mathrm{h}$, while for the three non-Saccharomyces strains the parameters were $15.56 \pm 1.68 \mathrm{~g} / \mathrm{L}$ and $0.484 \pm 0.06$ $\mathrm{g} / \mathrm{L} / \mathrm{h}$, respectively. In the mixed culture of three $S$. cerevisiae, all remained at the end, but one of them predominates, and of the non-Saccharomyces yeasts, Torulaspora delbrueckii was the predominant yeast, according with PFGE results. The results showed that the native yeasts are adapted to the agave juice used for bacanora production, and these yeasts would contribute to improve the ethanol yields and the organoleptic characteristics of bacanora.

Keywords: Bacanora; alcoholic fermentation; native yeast; S. cerevisiae; non-Saccharomyces.

\section{RESUMEN}

Bacanora es una bebida Mexicana derivada de agave, similar al tequila o mezcal producida de manera artesanal, por lo que sus características organolépticas varían altamente entre bacanoras. El objetivo de este estudio fue caracterizar y seleccionar levaduras nativas involucradas en el proceso artesanal de fermentación. Se realizó una pre-selección inicial basada en las características fenotípicas de 580 levaduras, y después una selección basada en sus características fermentativas en jugo de agave. Después de la preselección se eligieron tres S. cerevisiae y tres no-Saccharomyces. Al evaluar las características fermentativas el cultivo con Saccharomyces cerevisiae produjo al final de la fermentación, $25.51 \pm 1.19 \mathrm{~g} / \mathrm{L}$ de etanol, con una productividad volumétrica de etanol de $1.76 \pm 0.17 \mathrm{~g} / \mathrm{L} / \mathrm{h}$, mientras que para el cultivo con las levaduras de no-Saccharomyces se obtuvieron $15.56 \pm 1.68 \mathrm{~g} / \mathrm{L}$ y $0.484 \pm 0.06 \mathrm{~g} / \mathrm{L} / \mathrm{h}$ respectivamente. En el cultivo mixto de $\mathrm{S}$. cerevisiae, todas se mantuvieron al final, siendo una la predominante y en las levaduras no-Saccharomyces, Torulaspora delbrueckii fue la predominante esto según el seguimiento con PFGE. Las levaduras nativas están adaptadas al jugo de agave utilizado para la producción del bacanora y además pueden contribuir a mejorar el proceso fermentativo, así como, las características organolépticas sensoriales de esta exquisita bebida.

Keywords: Bacanora; fermentación alcohólica; levaduras nativas; S. cerevisiae; no-Saccharomyces.

\section{INTRODUCTION}

Bacanora is a Mexican distilled beverage made from agave, similar to tequila and mezcal. The organoleptic characteristics of the beverage vary highly from producer to producer, due to the artisanal process used for production (Nuñez, 2001; Aguirre-Rivera et al., 2016). According to the Official Mexican Standards for bacanora, the drink must be made only from Agave angustifolia Haw and produced in the area of origin denomination for bacanora (AODB) (AlvarezAinza et al., 2009; D.O.F., 2005). The process is similar for mezcal and tequila production. First, the agave core is cooked in ovens with mezquite-wood, to hydrolyze the inulin, then milled to obtain the must called "saite" and then fermented by native yeasts. Finally, fermented agave must be distilled and standardized to the particular touch of each producer (Moreno, 1998; Núñez, 2001; Yanez, 2003; De la Cruz, 2003).

From the Mexican distilled beverages from agave (tequila, mezcal and bacanora), only tequila batches keep a constant sensorial quality, since it is produced in large facilities with high technology. Mezcal and bacanora, on the other hand, have large variations in sensory quality, since they are produced using artisanal process and the spontaneous fermentation driven by the combined action of various species 
of yeasts and bacteria. Furthermore, only a specific specie of agave is used for production of tequila, another kind for bacanora, and several different species for mezcal (D.O.F., 2004; D.O.F., 2005; Aguirre-Rivera et al., 2017). In the tequila industry, most companies use spontaneous fermentation, in many cases due to the natural-fermentation policy of the company. Different S. cerevisiae strains utilized for wine, beer or whisky fabrication, and even bakery yeast, are used as started in some tequila industries, although this yeast is able to ferment the tequila must, this is not the best suited to carry out this process (Gschaedler et al., 2004).

Starter cultures are required for keeping the typical quality of wine, however, pure cultures of yeasts from the same area are more effective (Querol et al., 2003). It is believed that these yeasts, called "selected local yeast", are better because they are completely adapted to the climatic conditions, the raw material and they are partially responsible of the unique characteristics of the beverage (Mas et al., 2002; Querol et al., 2003). For example, in the study of Wondra and Berovic (2001), 29 native S. cerevisiae strains were evaluated during wine making, and found that only one of these strains produced an excellent wine, while 11 wines did not have good quality. The main desirable phenotypic characteristics to select a yeast culture, is resistance to adverse factors such as high concentrations of ethanol and low pH. In addition, other desirable characteristics are a short lag phase during fermentation, complete consumption of fermentable sugars and glycerol, and production of killer toxins. On the other hand, undesirable characteristics are production of $\mathrm{H}_{2} \mathrm{~S}$, volatile acids, and some of intermediate metabolites like acetaldehyde and pyruvate (Mas et al., 2002).

In addition, several studies have identified the importance of S. cerevisiae due to the role that it has on the modification of beverages. This could be depending on the inoculation process in the case of wine (Heart \& Fleet, 1983), or on how this yeast can be found at different points of tequila production (Lachance, 1995).

In another study, Alvarez-Ainza et al. (2015) observed a high variability between the $S$. cerevisiae yeast isolated in every one of the municipalities during the natural fermentations process on the bacanora production. Moreover, this study showed how some non-Saccharomyces yeasts exhibited Saccharomyces-like characteristics, which might have an important participation on the fermentation process. In relation to this, Arellano et al. (2008) evaluated the kinetic parameters and the formation of volatile compounds from native $S$. cerevisiae and Kloeckera $s p$. strains, isolated from agave juice from tequila production, and observed that all S. cerevisiae strains as well as Kloeckera species had a similar behavior, however, between these species the production of aromatic compounds was different. Furthermore, AlvarezAinza et al. (2013) evaluated the main compounds of bacanora produced in the area with origin denomination, and found a great variability in the products; they recommend the use of a correct yeast culture as started for the fermentation process, so this variability could be corrected. In a Lopez-Alvarez et al. (2016) study, the fermentation process in the elaboration of tequila was evaluated, carried out by comparing an ethanol yield in a Kluyveromices marxianus native strain and in a bakery strain of $S$. cerevisiae, the results showed that the K. marxianus strain reached $96 \%$ yield.

These studies support the idea that the Saccharomyces and non-Saccharomyces species play an important role in the fermentation process for tequila production, so they recommend the evaluation of mixed cultures. Therefore, the aim of this work was to select native yeast from a large group of S. cerevisiae and non-Saccharomyces strains isolated during the fermentation process of bacanora, and to evaluate the performance of the selected native yeast as started-mixed cultures for production of bacanora.

\section{MATERIALS AND METHODS Yeast Strain}

Two hundred and five S. cerevisiae strains and 375 noSaccharomyces yeast strains isolated from the fermentation tank of bacanora facilities, at different stages during the production of this beverage, were used (Collection of the laboratory of Microbiology in the Centro de Investigación en Alimentación y Desarrollo A. C., Hermosillo, Sonora, México). The yeasts were stored at $-70^{\circ} \mathrm{C}$ in a YEPD medium (yeast extract $10 \mathrm{~g} / \mathrm{L}$, peptone $20 \mathrm{~g} / \mathrm{L}$ and dextrose $20 \mathrm{~g} / \mathrm{L}$ ) with 30 $\%(v / v)$ glycerol.

\section{Analysis of some phenotypical characteristics of yeast}

Utilization of $1 \%(\mathrm{w} / \mathrm{v})$ glucose, fructose and inulin was assessed according to García-Galaz et al. (2004). Growth at 37 and $42^{\circ} \mathrm{C}$ was evaluated in PDA (Potato Dextrose Agar, Difco) plates acidified with tartaric acid $10 \%(\mathrm{w} / \mathrm{v})$ and incubated $48 \mathrm{~h}$ (D.O.F., 2004). Tolerance to ethanol was evaluated according to Lachance (1995), using 3, 5, 8, 10, 15 and $20 \%$ $(\mathrm{v} / \mathrm{v})$ ethanol. Growth at different $\mathrm{pH}$ was evaluated on PDA plates, the initial $\mathrm{pH}$ was adjusted with tartaric acid in a $\mathrm{pH}$ range from 2.5 to 7.5 , in 0.5 increments, and incubated at $30^{\circ} \mathrm{C}$ for $48 \mathrm{~h}$. $\mathrm{H}_{2} \mathrm{~S}$ production was evaluated on Bismuth Sulfite Agar (Difco) plates and incubating for 5 days at $30^{\circ}$ C (Caridi et al., 2002). Killer factor was also evaluated using the killer-sensitive strain CECT 1018 and the Killer strain CECT 1891 (Caridi et al., 2002) as references. Yeasts were cultivated in YEPD broth $1.8 \%(\mathrm{w} / \mathrm{v})$, with fructose instead of glucose, absorbance at $600 \mathrm{~nm}$ was followed until stationary phase and the length of the lag phase was determined.

\section{Evaluation of mixed cultures as starter for bacanora pro- duction}

Juice from Agave angustifolia Haw. The juice from agave was obtained from the saite of a producer; the saite was mixed with water and all the juice was filtered and collected. The final sugar concentration was adjusted to $12^{\circ}$ Brix $(55 \pm 3$ $\mathrm{g} / \mathrm{L}$ reducing sugars) and stored at $-10^{\circ} \mathrm{C}$.

Pre-inoculum and inoculum. The selected S. cerevisiae and non-Saccharomyces (Torulaspora delbrucekii, Pichia membranefaciens and Kluyveromyces marxianus) strains were 
evaluated. Each strain was inoculated in diluted fermentation medium, from cultures of each yeast stored at $-70^{\circ} \mathrm{C}$ in a YEPD medium, to obtain the pre-inoculum and the inoculum, the diluted agave juice ( $1: 2$ from an original of $12^{\circ}$ Brix) was incubated for $12 \mathrm{~h}$ at $30^{\circ} \mathrm{C}$ in $500-\mathrm{mL}$ Erlenmeyer flaks with $100 \mathrm{~mL}$ of agave juice, with low stirring (200 rpm). Two inoculums were used, one with three strains of $S$. cerevisiae (S. cerevisiae key 46, S. cerevisiae 591 and S. cerevisiae 1101) and another with three species of non-Saccharomyces (Torulaspora delbrucekii key 1227, Pichia membranefaciens key 807 and Kluyveromyces marxianus key 251).

Fermentation. Juice from Agave angustifolia Haw was sterilized in the fermentation tank $\left(121^{\circ} \mathrm{C}, 15 \mathrm{~min}\right)$, the sugar concentration was adjusted at $12^{\circ}$ Brix. The agave juice was supplemented with ammonium sulfate $(1 \mathrm{~g} / \mathrm{L})$. Fermentations were carried in $3 \mathrm{~L}$ bioreactor (Applikon, The Netherlands) at $30^{\circ} \mathrm{C}$ and $200 \mathrm{rpm}$, using $2.5 \mathrm{~L}$ of the agave juice; air was not supplemented. Yeast was inoculated to an initial concentration of $20,000,000$ cells $/ \mathrm{mL}$. Two fermentations were performed for each culture. The fermentation course was followed for $24 \mathrm{~h}$ and sampling was performed every hour during the first $12 \mathrm{~h}$ and each $2 \mathrm{~h}$ the remaining $12 \mathrm{~h}$.

\section{Analytical methods}

Biomass concentration was estimated by total count using a Neubauer chamber or dry weight. Total reducing sugar was determined in previously hydrolyzed ferment yeast-free must by DNS method (Miller, 1959). Viability was estimated after dying cells with methylene blue (Díaz-Montaño et al., 2008; Segura-García et al., 2015). Ethanol concentration was determined using an enzymatic method measurement in an YSI biochemical analyzer 2700 (Yellow Spring Instrument). Karyotype technique was determined by pulsed clamp electrophoresis (PFGE) according to Alvarez-Ainza et al., (2015) with some modifications, using the zymoliase-20T enzyme at the first step of the process to degrade the cell wall $(25 \mu \mathrm{g} /$ $\mathrm{mL}$, Seikaguru Corporation). S. cerevisiae YPH80 was used as molecular weight (Molecular Weight log Biolabs Inc.). The gel was stained with ethidium bromide and photograph with a GelDoc camera (BioRad).

\section{Statistics analysis}

The phenotypic characteristics analysis was conducted by BioNumerics software (Applied Maths 1998-2002), using UPGMA (Unweighted Pair Group Method with Arimetic Mean) and the DICE coefficient to obtain a dendrogram. The specific growth rate $(\mu)$, substrate consumed rate $\left(r_{s}\right)$, ethanol production rate $\left(r_{\mathrm{p}}\right)$, biomass and ethanol yields $\left(Y_{\mathrm{x} / \mathrm{s}^{\prime}} Y_{\mathrm{p} / \mathrm{s}}\right)$ as well as a maximal biomass production $\left(X_{\max }\right)$ kinetic parameters were obtained by fitting a three-parameter logistic model for the fermentation with Saccharomyces, and the Gompertz model for the fermentation with non-Saccharomyces, based on the highest predictive fit obtained $\left(\mathrm{R}^{2}\right)$, using the statistical package NCSS 2007(Kaysville, Utah, USA). The three-parameter logistic model states that: $Y=A /(1+B(E X P(-C T)))$, where $Y$ is the number of organisms in a given time; EXP is the exponential function; $\mathrm{A}$ is the asymptote; $\mathrm{B}$ denotes the displacement in the $X$ axis; $C$ is the growth rate, and $T$ is time. The Gompertz model states that: $Y=A(\operatorname{EXP}(-\operatorname{EXP}(-B(T-C))))$, where $Y$ is the response variable; EXP the exponential function; $A, B$, and $C$ are the parameters of equation, and $T$ is time.

\section{RESULTS AND DISCUSSION \\ Analysis of some phenotypical characteristics of yeast}

All S. cerevisiae strains fermented glucose and fructose, but only $43 \%$ (88 strains) fermented inulin. Of the nonSaccharomyces yeast, $8.2 \%$ did not ferment glucose, $7.4 \%$ were unable to ferment fructose and $57.3 \%$ could use inulin. Of the S. cerevisiae strains, $94 \%$ were able to grow at $37^{\circ} \mathrm{C}$ and $64 \%$ at $42^{\circ} \mathrm{C}$, and for the non-Saccharomyces yeast $97.4 \%$ were able to grow at $37^{\circ} \mathrm{C}$ and $95.8 \%$ at $42^{\circ} \mathrm{C}$. All yeasts were able to grow and resist ethanol concentrations in the range of $3-15 \%$, and $95 \%$ of S. cerevisiae yeast, as well as $95.7 \%$ of the non-Saccharomyces strains, were able to resist $20 \%$ ethanol. Only 8 S. cerevisiae and 170 non-Saccharomyces strains were unable to grow at $\mathrm{pH} 2.5$. Regarding $\mathrm{H} 2 \mathrm{~S}$ production, $17 \%$ of S. cerevisiae and $16.5 \%$ of non-Saccharomyces yeast strains resulted positive. The killer phenotype was present only in three Saccharomyces yeasts, 14 were killer-sensible and 257 were killer-neutral.

The individual carbohydrate fermentation was performed in order to assess the ability of yeast strains to use these sugars individually. In this study, glucose, fructose and inulin, were assessed, which in theory are the agave juice sugars for the bacanora production (Aguirre-Rivera, et al., 2017); when cooked, agave "piñas" hydrolyze the carbohydrate reserve, those are the predominating with other fructans identified as new fructans or agavins (Mancilla-Margalli and Lopez, 2006). The bacanora process is done by a thermal treatment, however during the cooking process, all the fructans present in the "piñas" cannot be hydrolyzed, therefore, we also assessed whether these yeasts strains ferment inulin. In this study, it is noted that not all the non-Saccharomyces used glucose with a fermentative process, it is well know that this species uses most the oxidative metabolism (Heard and Fleet, 1985; Ciani et al., 2016a; Ciani et al., 2016b). The yeast tolerance or ability to grow at 37 and $42^{\circ} \mathrm{C}$ was important because in the region where the beverage is produced, temperatures of up to $42^{\circ}$ are reached in summer, based on the reports for tequila and whisky fermentation (Diaz-Montaño et al., 2008; Walker and Hill, 2016). Optimum temperature for most yeast is $30-35^{\circ} \mathrm{C}$, but this temperature may increase by 2 or 3 degrees during the process, and in summer, it has been observed that during tequila fermentation temperatures up to $40^{\circ} \mathrm{C}$ are reached (Diaz-Montaño et al., 2008). The yeast ability for ethanol tolerance was performed by the recommendations of Lachance (1995). In that work, most of the Saccharomyces strains resisted up to $11 \%$ ethanol, and in the present work almost all yeasts resist $20 \%$. Moreover, in fermented musts of cane and agave juice between 4 and $6.5 \%$ ethanol are reached, so the native strains involved in the process of developing bacanora have this great quality (Heard and Fleet, 1985). The 
pH of the "saite" is between 5 and 6 , in some cases even lower (Fraizer and Westhoff, 1998), so in this study the survival of yeast at different $\mathrm{pH}$ was determined. Moreover, this study also evaluated the $\mathrm{H}_{2} \mathrm{~S}$ production on each of the strains because it is non-desirable (Mas et al., 2002; Caridi et al., 2005). Some bacanora-producers state that the "saite" sulfur aroma (rotten eggs) during the fermentation generates economic losses, since the batch is discarded (personal communication with producers).

The killer phenotype was present only in three $S$. cerevisiae strains, 14 S. cerevisiae were killer-sensible and the rest of the S. cerevisiae and all the non- Saccharomyces (257 strains) were killer-neutral. Figure 1 shows the corresponding dendrogram analysis result of the phenotypic characteristics, and it shows the suitable characteristics recommended by Alvarez-Ainza et al. (2009) for bacanora production. Cluster 8 has the suitable characteristics recommended and it is constituted by 40 yeasts, 30 of them are S. cerevisiae, and 10 are non-Saccharomyces strains. Killer phenotype might represent an antagonist mechanism between yeasts during spontaneous fermentation process (Romano et al., 2003). The native populations might be a relatively high number of killer-resistant strains to the toxin and low presence of strains with killer-killer phenotype. Moreover, killer native populations in each area could put in interrogative the inoculation of a killer-sensitive strain selected to observe its best oenological characteristics. It is then recommended to select strains that show the killer-neutro o killer-killer phenotype, because it favors when are used as starter culture (Rodríguez et al., 1998).

Figure 1 shows the results of the analysis performed by the BioNumerics program, where the coefficient Dice and UPGMA were used to obtain a dendrogram, where a group or cluster with the suitable characteristics recommended by Alvarez-Ainza et al. (2009) for the bacanora production, can be observed. This group is cluster 8 , constituted by 40 yeasts, 30 of S. cerevisiae and 10 of non-Saccharomyces strains. After the analysis of the phenotypic characteristics, the growth curves analyses were done. These analyses showed that the latency phase was diverse in the different kinds of yeast, where the non-Saccharomyces show latencies phases of up to 5 hours and the $S$. cerevisiae strains show no more than $2.5 \mathrm{~h}$. These results help to determinate the yeasts that are adapted to the medium with fructose, fermentable carbohydrate present in the agave juice (data not shown).

Later, three non-Saccharomyces yeasts with a latency phase under $2 \mathrm{~h}$ and different velocity of growth, were chosen for evaluation in mixed cultures. Likewise, 3 different species of non-Saccharomyces were chosen to be evaluated in mixed cultures: Kluyveromyces marxianus, Pichia membranefaciens and Toluraspora delbrueckii.

\section{Evaluation of mixed cultures as starter for bacanora pro- duction}

The time course of the Agave angustifolia Haw juice fermentation with Saccharomyces or non-Saccharomyces strains mixed cultures is shown on Figure 2 , and the

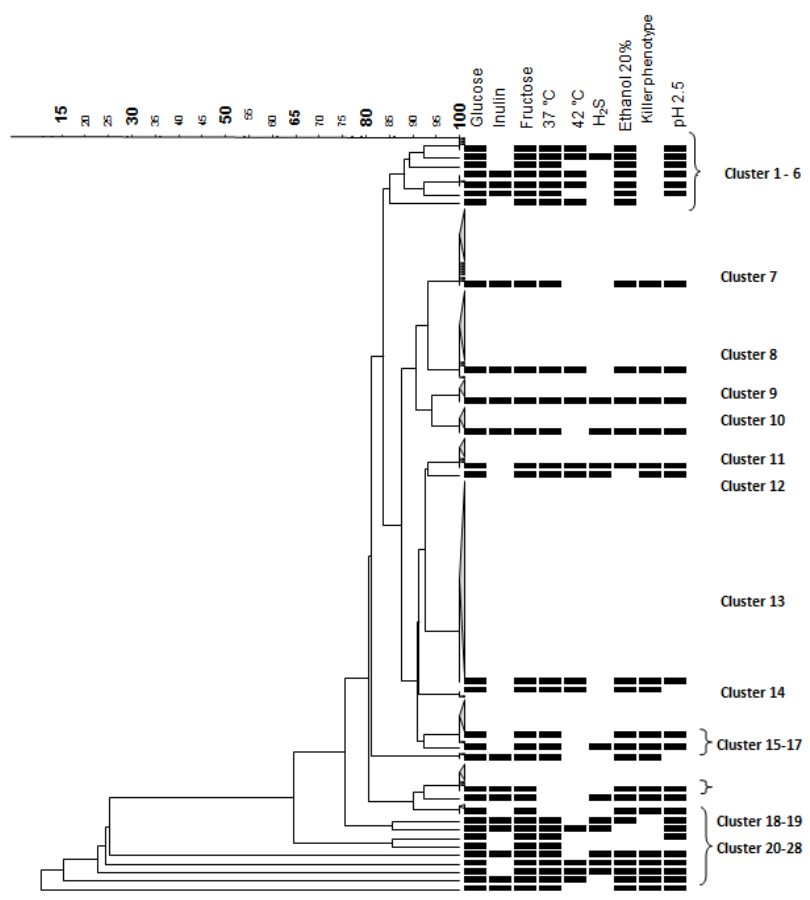

Figure 1. Phenotypic characteristics dendrogram of S. cerevisiae and nonSaccharomyces yeasts, obtained by the BioNumerics program using the coefficient Dice and UPGMA.

Figura 1. Dendrograma de las características fenotípicas de levaduras $S$. cerevisiae y no-Saccharomyces obtenido por el programa BioNumerics, utilizando el coeficiente Dice y UPGMA.

kinetic parameters on Table 1, where the P-value of the statistical analysis carried out with variance of kinetic parameters of the culture obtained using a logistic (S. cerevisiae culture) or Gompers model (non-Saccharomyces culture). The Saccharomyces mixed culture grew faster, and the maximal biomass had also greater numbers than the non-Saccharomyces, which yielded a maximal biomass of $8.27 \pm 0.24 \mathrm{~g} / \mathrm{L}$, with reducing sugars depleted between 18-20 h. On the other hand, the mixed non-Saccharomyces strains culture yielded a maximum biomass of $3.87 \pm 1.14 \mathrm{~g} / \mathrm{L}$ and reducing sugars were not depleted.

The Saccharomyces mixed culture (S. cerevisiae key 46 , S. cerevisiae 591 and S. cerevisiae 1101) was more efficient than non-Saccharomyces (Torulaspora delbrucekii key 1227, Pichia membranefaciens key 807 and Kluyveromyces marxianus key 251 ) to produce ethanol. The first produced up to $25.51 \pm 1.19$ $\mathrm{g} / \mathrm{L}$ with a volumetric productivity of $1.76 \pm 0.17 \mathrm{~g} / \mathrm{L} / \mathrm{h}$, while non-Saccharomyces strains produced $15.56 \pm 1.68 \mathrm{~g} / \mathrm{L}$ of ethanol with a volumetric productivity of $0.484 \pm 0.06 \mathrm{~g} / \mathrm{L} / \mathrm{h}$. The kinetic parameter evaluated in the fermentations on this study, indicates the degree of adaptation of the microorganisms to the culture. The yeasts in mixed cultures were able to grow and achieve transformation of sugars into ethanol; it should be noted here that in the case of mixed cultures, there is also competition between the inoculated strains and the best adapted will be the predominant.

Similar results were reported by Arellano et al. (2008), 


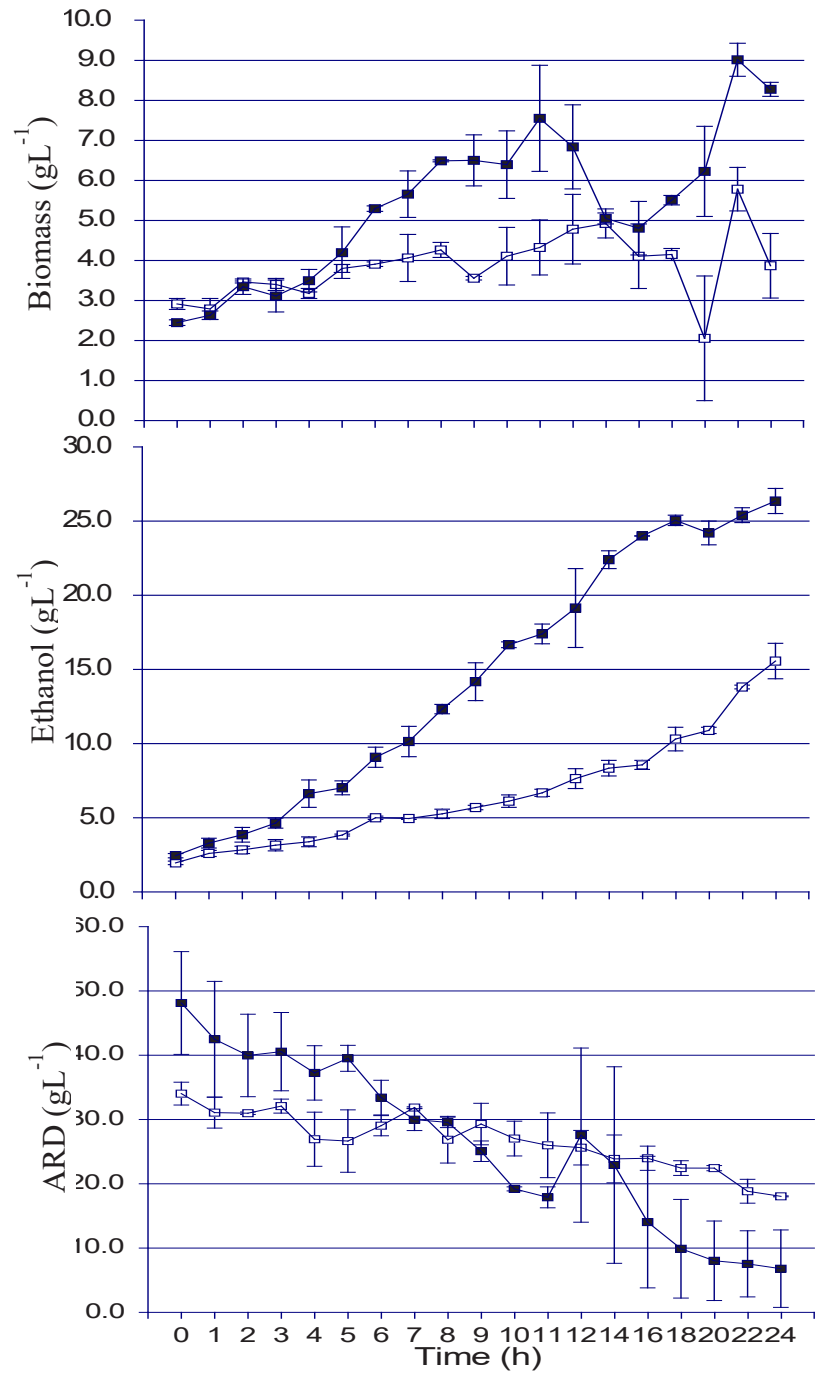

Figure 2. Fermentation kinetic profiles of cultures with S. cerevisiae ( $\square$ ) and non-Saccharomyces ( $\mathbf{\square})$. ARD: reduction sugar concentration profile; Ethanol: ethanol concentration profile; Biomass: biomass concentration profile (Mean \pm standard error).

Figura 2. Perfil cinético de la fermentación de cultivos de S. cerevisiae ( $\mathbf{\square})$ y no- Saccharomyces ( $\square$ ). ARD: perfil de reducción de la concentración de azúcares; Etanol: perfil de la concentración de etanol; Biomasa: perfil de la

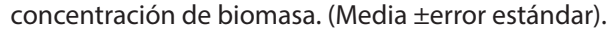

they determined the kinetic parameters of wild yeast isolated from agave juice during tequila fermentation. In order to do this, they inoculated S. cerevisiae and Kloeckera sp isolates as monocultures in agave juice, and their results were in alcohol produced from 24 to $32 \mathrm{~g} / \mathrm{L}$ being the S. cerevisiae specie the best alcohol producer. Similarly, Díaz-Montaño et al. (2008) study with Agave tequilana Weber juice, shows S. cerevisiae and Kloeckera with results between 21-43 g/L the etanol produced at the end.

Di Serio et al. (2003) evaluated bakery yeast on YEPD medium, and other medium made with molasses and different salts, reporting different results with respect to this study. Values reported by Di serio et al. (2003) on the maximum growth rate (1.26 \pm 0.11 per $\mathrm{h})$ and biomass yield per sub-
Table 1. Kinetics parameters of the fermentation of agave juice inoculated with mixed cultures of $S$. cerevisiae and non-Saccharomyces strains.

Tabla 1. Parámetros cinéticos en la fermentación de jugos de agave inoculados con cultivos mixtos de cepas de Saccharomyces cerevisiae y noSaccharomyces.

\begin{tabular}{lccc}
\hline Parameter & $\begin{array}{c}\text { S. cerevisiae } \\
\text { mixed culture }\end{array}$ & $\begin{array}{c}\text { Non- } \\
\text { Saccharomyces } \\
\text { mixed } \\
\text { culture }\end{array}$ & P value \\
\hline$\mu($ per $\mathrm{h})$ & $0.29 \pm 0.09$ & $0.24 \pm 0.06$ & 0.6418 \\
$r s(\mathrm{~g} / \mathrm{L} / \mathrm{h})$ & $3.84 \pm 0.12$ & $1.03 \pm 0.22$ & $0.0008^{*}$ \\
$r p(\mathrm{~g} / \mathrm{L} / \mathrm{h})$ & $1.76 \pm 0.17$ & $0.48 \pm 0.03$ & $0.0000^{*}$ \\
$Y \mathrm{Y} / \mathrm{s}(\mathrm{g} / \mathrm{g})$ & $0.07 \pm 0.02$ & $0.24 \pm 0.03$ & 0.0733 \\
$Y \mathrm{p} / \mathrm{s}(\mathrm{g} / \mathrm{g})$ & $0.45 \pm 0.06$ & $0.47 \pm 0.03$ & 0.8584 \\
Biomass $(\mathrm{g} / \mathrm{L})$ & $8.27 \pm 0.24$ & $3.86 \pm 1.14$ & $0.0331^{*}$ \\
\hline Total Alcohol $(\mathrm{g} / \mathrm{L})$ & $25.5 \pm 1.19$ & $15.56 \pm 1.68$ & $0.0179^{*}$ \\
\hline Fermentation time $(\mathrm{h})$ & 18 & $>24$ & \\
\hline
\end{tabular}

$\mu$ : specific growth rate; $r s$, substrate consumed rate; $r p$, ethanol production rate; $Y x / s$, biomass yield; $Y p / s$, ethanol yield. Each value represents the average \pm standard deviation of duplicate determinations of two fermentations. * Statistical difference: $\mathrm{P}<0.05$.

strate consumption $(0.723 \pm 0.069 \mathrm{~g} / \mathrm{g})$, are higher than our results. This means that the YEPD medium and the molasses are more complete than the agave juice, or that the agave juice has inhibitors that affect the yeast, like some maillard compounds produced in the agave cooking, such as furfural. On the other hand, the results obtained are encouraging because the Bacanora producer obtained less than $20 \mathrm{~g} / \mathrm{L}$ of ethanol in their fermentations, and in longer time with mixed S. cerevisiae cultures the production was $27.5 \%$ higher.

The karyotypes of the yeast found at the end of the fermentation with mixed cultures (Figure 3), show that using S. cerevisiae, the strain with the key 1101 predominated at the end, but the other two also developed. In the non-Saccharomyces-mixed culture, Torulaspora delbrueckii predominated, and some Kluyveromyces marxianus strains were occasionally found, while Pichia membranefaciens was not found at the end, probably because this yeast is most sensible to alcohol or other products generated in the process. The yeast of Saccharomyces and non-Saccharomyces species are often found in alcoholic fermentations, for the production of wine, whisky and other agave beverages (Esteve-Zarzoso et al., 2001; Romano et al., 2003; Fiore et al., 2005; Diaz-Montaño, 2008; Fleet, 2008; Walker and Hill, 2016). The participation of the adequate Saccharomyces yeast has an important impact in ethanol production during fermentation, while the non-Saccharomyces yeasts in the final aroma; Torulaspora delbrueckii can be used to modulate sensory characteristics, such as acidity (Bely et al., 2008). Also, the use of S. cerevisiae is recommended to prevent native yeast growth on must, and the reduction of fermentation time (García et al., 2017). García et al. (2017) found that sequential cultures have produced more different wines providing organoleptic properties associated with the non-Saccharomyces strains used. Nolasco-Cancino et al. (2018) evaluated S. cerevisiae and non-Saccharomyces yeasts in single and mixed cultures in maguey juice (Agave angustifolia) used for mezcal production; the authors con- 


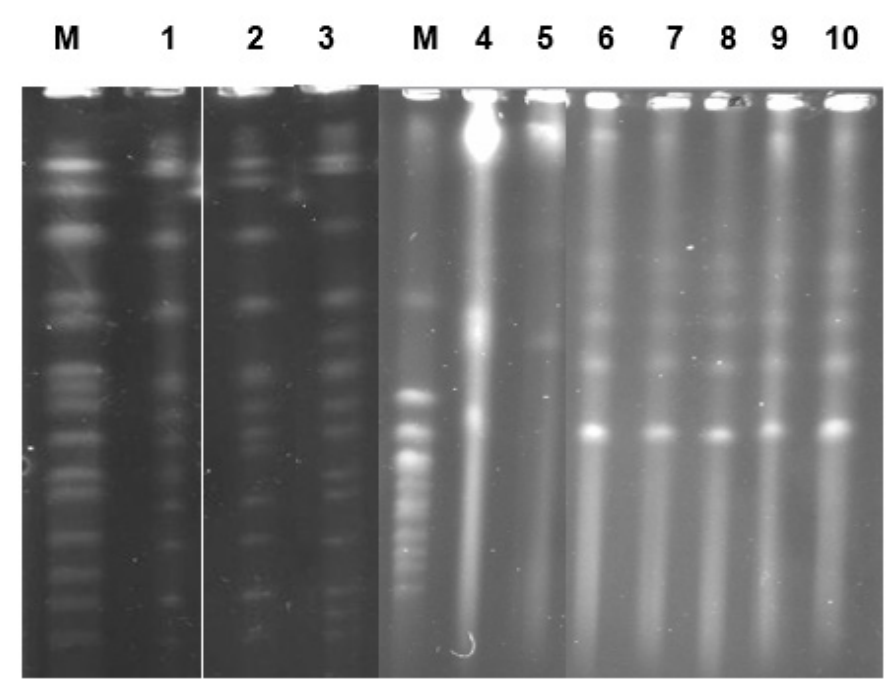

Figure 3. Karyotypes of yeasts found at the end of each culture probes fermentation.

M: molecular weight of S. cerevisiae YPH80; 1-3, S. cerevisiae strains isolated at the end of the fermentation; $4, K$. marxianus control; 5, P. membranefaciens control; $6, T$. delbrueckii control; 7-10, strains isolated at the end of the fermentation from the no-Saccharomyces culture.

Figura 3. Cariotipos de las levaduras encontradas al final de la fermentación de cada uno de los cultivos probados.

cluded that these cultures revealed their possible influence on volatile compound production, suggesting that the yeasts combination could contribute to improve the organoleptic characteristics of artisanal mezcal.

\section{CONCLUSIONS}

The native $S$. cerevisiae yeast isolated and selected from the Agave angustifolia Haw juice fermentation, can be used as starter mixed culture and the concentration of ethanol increases compared to the spontaneous fermentation in the production facility. Since Torulaspora delbrueckii ferments agave juice and predominated along the process in our study, it could be used together with S. cerevisiae to improve the fermentative process and enhance the sensory characteristics of bacanora but further studies are required.

\section{ACKNOWLEDGEMENTS}

The authors would like to thank and devote this manuscript to Evelia Acedo-Felixt who made this work possible. The authors also thank to the producers involves in the Bacanora production, and Gutiérrez-Franco, L. E. by proofreading.

\section{REFERENCES}

Aguirre-Rivera, J., Aldrete-Herrera, P., Alvarez-Ainza, M. et al. 2017. Panorama del aprovechamiento de los agaves en México. Estado del Arte publicado por AGARED, Red Temática Mexicana Aprovechamiento Integral Sustentable y Biotecnología de los Agaves. ISBN: 978-607-97548-5-3. [consultado 07 febrero de 2020]. Available from: http:// www.agared.org/libro-panorama-de-los-agaves.
Alvarez-Ainza, M., González-Ríos, H., González-León, A., Valenzuela-Quintanar, A. and Acedo-Félix, E. 2013. Quantification of major volatile compounds in artisanal Bacanora. American Journal of Analytical Chemistry. 4: 683688.

Alvarez-Ainza, M., Zamora-Quiñonez, K. and Acedo-Félix, E. 2009. Perspectivas para el uso de levaduras nativas durante la elaboración de bacanora. Revista Latinoamericana de Microbiología. 51: 58-63.

Alvarez-Ainza, M., Zamora-Quiñonez, K., Moreno-lbarra, G. and Acedo-Felix, E. 2015. Genomic diversity of Saccharomyces cerevisiae yeast associated with alcoholic fermentation of bacanora produced by artisanal methods. Applied Biochemestry and Biotechnology. 175: 2668-2676.

Arellano, M., Pelayo, C., Ramírez, J. and Rodríguez, I. 2008. Characterization of kinetic parameters and the formation of volatile compounds during the tequila fermentation by wild yeast isolated from agave juice. Journal of Industrial Microbiology and Biotechnology. 35: 835-841.

Bely, M., Stoeckle, P., Masneuf-Pomarède, I. and Dubourdieu, D. 2008. Impact of mixed Torulaspora delbrueckii-Saccharomyces cerevisiae culture on high-sugar fermentation. International Journal of Food Microbiology. 122(3): 312-320.

Caridi, A., Cufari, A., Ramondino, D. 2002. Isolation and clonal pre-selection of enological Saccharomyces. Journal of General Applied Microbiology. 48: 261-267.

Ceccato-Antonini, S., Tosta, C. and da Silva, C. 2004. Determination of yeast killer activity in fermenting sugarcane juice using selected ethanol-making strains. Brazilian Archives Biology and Technology. 47: 13-23.

Ciani, M., Capece, A., Comitini, F., Canonico, L., Siesto, G. and Romano, P. 2016a. Yeast interactions in inoculated wine fermentation. Frontiers in Microbiology. 7(555): 1-7.

Ciani, M., Morales, P., Comitini, F. Tronchioni, J., Canonico, L., Curiel, J., Oro, L., Rodriguez, A. and Gonzalez, R. 2016b. Nonconventional yeast species for lowering ethanol content of wines. Frontiers in Microbiology. 7(642): 1-13.

Combina, M., Elia, A., Mercado, L., Catania, C., Ganga, A. and Martinez, C. 2005. Dynamics of indigenous yeast populations during spontaneous fermentation of wines from Mendoza, Argentina. International Journal of Food Microbiology. 99: 237-243.

D. O. F. 1998. Norma Oficial Mexicana NOM-070-SCFI-1994, Bebidas alcohólicas-mezcal-especificaciones de elaboración, envasado y etiquetado. [consultado 07 febrero de 2020]. Available from: http://www.colpos.mx/bancodenormas/ noficiales/NOM-070-SCFI-1994.PDF.

D. O. F. 2004. Norma Oficial Mexicana NOM-006-SCFI-2004, Bebidas alcohólicas-tequila-especificaciones de elaboración, envasado y etiquetado. [consultado 07 febrero de 2020]. Available from: https://www.crt.org.mx/images/ Documentos/NOM-006-SCFI-2005.pdf.

D. O. F. 2005. Norma Oficial Mexicana NOM-168-SCTI-2004, Bebidas alcohólicas-Bacanora-especificaciones de elaboración, envasado y etiquetado. [consultado 07 febrero de 2020]. Available from: https://dof.vlex.com.mx/vid/scfialcoholicas-bacanora-envasado-28151559

De la Cruz, C. 2003. Sembrar maguey y producir Bacanora en el rancho. Revista Rancho. 11: 22-23.

Di Serio, M., Aramo, P., E. de Alteris, Tesser, R. and Santacesaria, E. 2003. Quantitative analysis of the key factors affecting yeast 
arowth. Industrial and Engineering Chemistry Research. 42 (21): 5109-5116.

Díaz-Montaño, D., Délia, M., Estarrón-Espinoza, M. and Strehaiano P. 2008. Fermentative capability and aroma compound production by yeast strains isolated from Agave tequilana Weber juice. Enzyme and Microbial Technology. 42: 608-616.

Esteve-Zarzoso, B., Peris-Torán, M., García-Maiquez, E., Uruburu, F. and Querol, A. 2001. Yeast populations dynamics during the fermentation and biological aging of sherry wines. Applied Environmental and Microbiology. 67(5): 2056-2061.

Fiore, C., Arrizon, J., Gschaedler, A., Flores, J, and Romano, P. 2005. Comparison between yeasts from grape and agave must for traits of technological interest. World Journal of Microbiology and Biotechnology. 22: 1141-1147.

Fleet, G. 2008. Wine yeast for the future. FEMS Yeast Research. 8(7), 979-995.

Frazier, W. and Westhoff, D. 1998. Microbiología de los Alimentos. España. Ed. Acribia, S.A.

García, M., Esteve-Zarzoso, B., Crespo, J., Cabellos, J. and Arroyo, T. 2017. Yeast monitoring of wine mixed or sequential fermentations made by native strains from D.O "Vinos de Madrid" using Real-Time quantitative PCR. Frontiers in Microbiology. 8(2520): 1-15.

García-Galaz, A., Pérez-Morales, R., Díaz-Cinco, M. and AcedoFélix, E. 2004. Resistance of Enterococcus strains isolated from pigs to gastrointestinal tract and antagonistic effect against Escherichia coli K88. Revista Latinoamerican de Microbiología. 34: 5-11.

Gschaedler, M., Ramirez, J., Díaz, D., Herrera, J., Arellano, M., Arrizón, L. and Pinal, L. 2004. CIATEJ. Fermentación etapa clave en la elaboración de tequila, Chapter 4. In Ciencia y tecnología del Tequila Avances y Perspectivas. Pp. 62-120. In: Gschaedler MAC (ed) Centro de Investigación y Asistencia en Tecnología y Diseño del Estado de Jalisco, A.C. Guadalajara, Jalisco, México.

Guillamón, J., Sabate, J. and Barrio, E. 1998. Rapid Identification of wine yeast species based on RFLP analysis of the ribosomal internal transcribed spacer (ITS) region. Archives of Microbiology. 169: 387-392.

Heard, G., and Fleet, G. 1985. Growth of natural yeast flora during the fermentation of inoculated wines. Applied and Environmental Microbiology. 50(3): 727-728.

Lachance, M. 1995. Yeast communities in a natural tequila fermentation. Journal of Antonie Van Leeuwenhoek. 68: 151-160.

Lopez-Alvarez, A., Díaz-Pérez, A., Sosa-Aguirre, C., MacíasRodríguez, L., Campos-García, J. 2012. Ethanol yield and volatile compound content in fermentation of agave must by Kluyveromyces marxianus UMPe- 1 comparing with Saccharomyces cerevisiae baker's yeast used in tequila production. Journal of Bioscience and Bioengineering. 113 (5): 614-618.

Mancilla-Margalli, N.D. and Lopez M. 2006. Water-Soluble Carbohydrates and fructan structure patterns from Agave and Dasylirion species. Journal of Agricultural and Food Chemestry. 54: 7832-7839

Mas, A., Torija, M., Beltrán, G., Novo, M., Hierro, N., Poblet, M., Rozés, N. and Guillamón, J. 2002. Selección de Levaduras. Tecnología del Vino, Fermentos. 39-44. http://www.alcion.es

Miller, G. 1959. Use of dinitrosalicylic acid reagent for determination of reducing sugar. Analytical Chemistry. 31: 426-428.

Moreno, S. 1998. Agave angustifolia. La bacanora desde su origen hasta nuestros días. Una bebida sonorense con calidad internacional. Instituto del medio ambiente y el desarrollo de Sonora (Imades). Revista Entorno. 2: 3-5.

Núñez, L. 2001. La producción de mezcal Bacanora. Centro de Investigación en Alimentación y Desarrollo, A.C. Hermosillo, Sonora, México.

Nolasco-Cancino, H., Santiago-Urbina, J., Wacher, C. and RuízTeran, F. 2018. Predominant yeasts during artisanal mezcal fermentation and their capacity to ferment maguey juice. Frontiers in Microbiology. 9(2900):1-12.

Querol, A., Fernández-Espinar, M., del Olmo M. and Barrio, E. 2003. Adaptative evolution of wine yeast. International Journal of Food Microbiology. 86: 3-10.

Rodríguez, L., Abad, D., Gómez, J., Casanova, J. and Lema, C. 1998. Fenotipo killer: Distribución en la comarca de la Ribiera sacra en las poblaciones de Saccharomyces cerevisiae. Ciencia y Tecnología de Alimentos. 2: 33-37.

Romano, P., Fiore, C., Paraggio, M., Caraso, M. and Capece, A. 2003. Function of yeast species and strains in wine flavor. International Journal of Food Microbiology. 86: 169-180.

Segura-García, L., Taillandier P., Brandam C. and Gschaedler, A. Fermentative capacity of Saccharomyces and nonSaccharomyces in agave juice and semi-synthetic medium. 2015. Food Science and Technology, 60 (1): 284-291.

Walker, G., M. and Hill, A. 2016. Saccharomyces cerevisiae in the production of whisk(e)y. Beverages. 2(38): 1-15.

Wondra, M. and Berovic, M. 2001. Analyses of aroma components of Chardonnay wine fermented by different yeast strains. Food Technology and Biotechnology. 39(2): 141-148.

Yanez, G. 2003. El maguey de Bacanora (Agave angustifolia). Instituto del medio ambiente y el desarrollo de Sonora (Imades). Revista Entorno. 11: 5-11 